\title{
The diagnosis of genital herpes - beyond culture: An evidence-based guide for the utilization of polymerase chain reaction and herpes simplex virus type-specific serology
}

\author{
S Ratnam PhD MPH FCCM ${ }^{1}$, A Severini MD ${ }^{2}$, G Zahariadis MD FRCPC ${ }^{3}$, \\ $M$ Petric PhD FCCM ${ }^{4}$, B Romanowski MD FRCPC 5
}

\begin{abstract}
S Ratnam, A Severini, G Zahariadis, M Petric, B Romanowski. The diagnosis of genital herpes - beyond culture: An evidencebased guide for the utilization of polymerase chain reaction and herpes simplex virus type-specific serology. Can J Infect Dis Med Microbiol 2007;18(4):233-240.
\end{abstract}

Accurate identification of persons with genital herpes is necessary for optimal patient management and prevention of transmission. Because of inherent inaccuracies, clinical diagnosis of genital herpes should be confirmed by laboratory testing for the causative agents herpes simplex virus type 1 (HSV-1) and HSV type 2 (HSV-2). Further identification of the HSV type is valuable for counselling on the natural history of infection and risk of transmission. Laboratory methods include antigen detection, culture, polymerase chain reaction (PCR) and conventional and type-specific serology (TSS). PCR has, by far, the greater sensitivity and should be the test of choice for symptomatic cases. HSV-2 TSS is indicated for patients with genital lesions in whom antigen detection, culture or PCR fail to detect HSV, and for patients who are asymptomatic but have a history suggestive of genital herpes. HSV-2 TSS is further indicated for patients infected with HIV. HSV-2 TSS along with HSV-1 TSS may be considered, as appropriate, in evaluating infection and/or immune status in couples discordant for genital herpes, women who develop their first clinical episode of genital herpes during pregnancy, asymptomatic pregnant women whose partners have a history of genital herpes or HIV infection, and women contemplating pregnancy or considering sexual partnership with those with a history of genital herpes. The above should be performed in conjunction with counselling of infected persons and their sex partners.

Key Words: Diagnosis; Genital herpes; HSV-1; HSV-2; PCR; Typespecific serology

G enital herpes, a recurrent life-long infection caused by J herpes simplex virus type $1(\mathrm{HSV}-1)$ and HSV type 2 (HSV-2), is one of the most prevalent sexually transmitted infections (STIs) in industrialized countries (1). It causes considerable morbidity for those infected, increases the risk of HIV acquisition and transmission, and may lead to congenital and neonatal infections (2-4). Sexual transmission can be decreased by approximately 50\% using suppressive therapy, which reduces recurrences and asymptomatic shedding (5).
Le diagnostic d'herpès génital au-delà de la culture : guide fondé sur des données probantes en vue de l'utilisation de la réaction en chaîne de la polymérase et du test sérologique spécifique de type de virus de l'herpès simplex

Il importe de bien repérer les patients atteints d'herpès génital afin de permettre une prise en charge optimale et de prévenir la transmission de l'infection. En raison de son manque inhérent de fiabilité, le diagnostic clinique d'herpès génital devrait être confirmé par des analyses de laboratoire afin de distinguer le type de virus de l'herpès simplex (VHS) en cause, soit celui de type 1 (VHS1) ou celui de type 2 (VHS2). Une exploration plus poussée du type de virus est utile dans les consultations sur l'évolution naturelle de l'infection et les risques de transmission. Les analyses de laboratoire comprennent la détection de l'antigène, la culture, la réaction en chaîne de la polymérase (RCP), le test sérologique général et le test sérologique spécifique (TSS) de type de virus. La RCP est, de loin, l'analyse qui offre la plus grande sensibilité, et elle devrait être l'épreuve de première intention dans les cas symptomatiques. Le TSS-VHS2 est indiqué chez les patients qui présentent des lésions génitales mais qui obtiennent des résultats négatifs à la détection de l'antigène, à la culture ou à la RCP, toutes des analyses visant à déceler la présence du VHS, et chez les patients qui ne présentent pas de symptômes mais qui ont des antécédents évocateurs d'herpès génital. Le TSS-VHS2 est aussi indiqué chez les personnes infectées par le VIH. On peut également envisager le TSS-VHS2 ainsi que le TSS-VHS1, suivant le cas, dans l'évaluation de l'infection ou de l'état immunitaire dans les couples divergents à l'égard de l'herpès génital, chez les femmes qui connaissent leur premier épisode clinique d'herpès génital durant la grossesse, chez les femmes enceintes qui ne présentent pas de symptômes mais dont le partenaire a des antécédents d'herpès génital ou d'infection par le VIH ou encore chez les femmes qui souhaitent devenir enceintes ou qui envisagent d'établir une vie sexuelle avec un partenaire ayant des antécédents d'herpès génital. Toutes ces mesures devraient être accompagnées de consultations à l'intention des personnes infectées et de leur partenaire sexuel.

The use of condoms can reduce transmission, as can disclosure of HSV status by infected individuals to their sex partners before any contact $(6,7)$. A recent report (8) indicated that the seroprevalence of HSV-2 may, in fact, be declining in the United States (US), although the incidence of HSV-1 in genital herpes is increasing. Up to $90 \%$ of those with HSV infection are unaware of their status, greater than $50 \%$ shed HSV subclinically in the genital area and at least 70\% of transmissions occur during periods of asymptomatic shedding

${ }^{1}$ Public Health Laboratory, St John's, Newfoundland and Labrador; ${ }^{2}$ The National Microbiology Laboratory, Public Health Agency of Canada,

Winnipeg, Manitoba; ${ }^{3}$ The Provincial Laboratory for Public Health, Departments of Medical Microbiology and Immunology and Laboratory

Medicine and Pathology, Faculty of Medicine and Dentistry, University of Alberta, Edmonton, Alberta; ${ }^{4}$ The BC Centre for Disease Control,

Vancouver, British Columbia; ${ }^{5}$ Division of Infectious Diseases, Faculty of Medicine and Dentistry, University of Alberta, Edmonton, Alberta

Correspondence: Dr S Ratnam, Public Health Laboratory, 100 Forest Road, St John's, Newfoundland and Labrador A1A 329.

Telephone 709-777-6568, fax 709-777-7070, e-mail sam.ratnam@easternhealth.ca 
$(1,2,9)$. A recent editorial commentary (10) called for a national genital herpes control program in the US. There are no coordinated efforts in Canada to improve laboratory diagnosis to identify asymptomatic cases and implement education on HSV and risk-reduction counselling.

There is a need to differentiate between HSV-1 and HSV-2 infections because there are important differences between the two viruses in terms of epidemiology, natural history, clinical implications and outcome. In clinically recognized cases of genital herpes, laboratory diagnosis has been traditionally made by virus isolation in cell culture and antigen detection by direct fluorescent antibody test or enzyme immunoassay (EIA). However, these methods have limitations and cannot be used reliably to identify asymptomatic cases (11-13). There has been increasing utilization of nucleic acid amplification tests (NATs) such as polymerase chain reaction (PCR) assays for detecting HSV. PCR assays for diagnosing genital herpes constitute the most sensitive method for detection of HSV in both symptomatic individuals and asymptomatic shedders (12). Furthermore, the development of HSV type-specific serology (TSS) tests based on purified glycoprotein $\mathrm{G}(\mathrm{gG})$, which differentiates between HSV-1 and HSV-2 infection, has provided an important tool for the diagnosis of genital herpes (14-18). The appropriate use of HSV PCR and TSS tests requires an understanding of the pathogenesis of genital herpes and, as with any diagnostic test, the indications for, and timing and interpretation of the tests must be understood before testing is requested or offered

A recent publication (19) in The Canadian Journal of Infectious Diseases $\mathcal{E}$ Medical Microbiology, as part of the Canadian STI best practice laboratory guidelines series, has addressed the laboratory diagnosis of HSV infections. The present report provides current evidence-based guidance to laboratories on the use of HSV PCR and TSS tests and to physicians on the indications for these tests and their interpretations.

\section{BACKGROUND AND RATIONALE}

HSV-2 is the predominant cause of recurrent genital herpes. In British Columbia, HSV-2 seroprevalence among pregnant women was reported to be $17 \%$, and as high as $28 \%$ in those between 40 to 44 years of age (20). In Alberta, 19\% of STI patients were found to be seropositive for HSV-2 (21). Studies in Ontario and Newfoundland $(22,23)$ among women of childbearing age, indicated that the overall prevalence of HSV-2 antibodies ranged between $9 \%$ and $6 \%$, respectively. This suggested geographical and demographic differences in HSV-2 prevalence within Canada. In the US, the seroprevalence of HSV -2 was reported to be $22 \%$, and increased in populations with higher risks of STIs $(2,24)$. Primary HSV-1 infection usually occurs during childhood, and is mainly associated with orofacial lesions. The majority of the Canadian population has been infected by HSV-1, as evidenced by the high prevalence of HSV -1 antibodies in the general population. This is in the range of $52 \%$ to $65 \%$ in adults in Alberta (21), and over $80 \%$ among women of childbearing age in Ontario and Newfoundland $(22,23)$. Genital infection with HSV-1 is thought to occur most commonly through oral-genital contact. While the severity of genital herpes episodes is similar between HSV-1 and HSV-2, HSV-1 genital infections are associated with less frequent recurrences and viral shedding than HSV-2 (25-27). Across Canada, there are geographical differences in the distribution of HSV-1 and HSV-2 in genital herpes, with British Columbia having a higher incidence of infection due to HSV-2 (unpublished data) while in Alberta, it is equally split between HSV-1 and HSV-2 (unpublished data). In contrast, in Nova Scotia and Newfoundland, there is a higher incidence of genital herpes due to HSV-1 (28, unpublished data). An increasing or a higher incidence of genital herpes due to HSV-1 has also been reported in a number of studies $(8,25,29,30)$.

Primary genital infection with HSV is followed by viral latency in the sensory sacral ganglion; the recurrent reactivation of genital herpes may be symptomatic or asymptomatic. A majority of patients with genital HSV infection are unaware of their infection because they may be asymptomatic or the symptoms and signs may not be recognized; thus, genital herpes is underdiagnosed $(1,2)$. More importantly, individuals with genital herpes are known to shed the virus asymptomatically from the genital area ('boxer short distribution') at variable frequencies regardless of the site of symptomatic recurrences (31); the transmission of genital herpes mostly occurs during periods of asymptomatic shedding (9). From a public health standpoint, there is concern that such individuals can serve as a reservoir of infection and can continue to spread the virus unknowingly to their contacts. Identification of such cases, coupled with education on HSV and preventive counselling, is central to an effective public health strategy.

Numerous studies $(32,33)$ have shown an interaction between HSV-2 and HIV. HSV-2 infection facilitates acquisition of HIV by at least twofold (34), may accelerate the course of HIV progression, and is a significant cause of morbidity and mortality in persons infected with $\operatorname{HIV}(33,35)$. Additionally, HIV-positive individuals have more frequent, more severe and chronic lesions associated with longer recurrences of genital herpes, and increased rates of asymptomatic genital shedding of HSV-2 compared with HIV-negative individuals $(34,36,37)$. Coinfection with HIV and HSV-2 is very common, ranging from $50 \%$ to $90 \%$ (37). In Canada, preliminary data based on 572 HIV-positive cases indicate an overall HSV-2 seroprevalence of $55 \%$, ranging from $46 \%$ in men who have sex with men to $57 \%$ in heterosexuals, $61 \%$ in injection drug users and $74 \%$ in HIV-infected individuals from endemic regions (unpublished data). HSV suppressive therapy of HIV-infected persons not only decreases frequency and severity of HSV recurrences and shedding, but can also result in a decrease in HIV levels in the blood and genital tract $(37,38)$. More important, coinfected individuals often do not have a clinical history of genital herpes, and identifying those infected with HSV may facilitate optimal patient management together with riskreduction counselling for both infections to help prevent further transmission (16). Therefore, it is of benefit to routinely offer HSV-2 TSS to HIV-infected persons $(16,33,37)$.

Among couples discordant for genital herpes by history, up to one-quarter have concordant HSV-2 serology $(17,39)$. The risk of acquisition of genital herpes among discordant couples has been reported to be $19 \%$ per year for male to female transmission versus $5 \%$ per year for female to male transmission (9). Genital herpes during pregnancy is of particular concern because it may increase the risk of neonatal herpes (40). For women who acquire primary herpes during pregnancy, the risk to the neonate is dependent on the stage of pregnancy at which the mother acquires infection, with the greatest risk posed by a primary infection occurring late in the third trimester when the risk of neonatal infection is as high as $50 \%$ $(40,41)$. Conversely, the risk of transmission is low for those 
who seroconvert before delivery $(3,41)$. With appropriate management, women who have been diagnosed with genital herpes before they become pregnant are at low risk (in the range of $2 \%$ to $8 \%$ ) of transmitting the infection to their newborn (3). Approximately $90 \%$ of all neonatal HSV infections are transmitted during delivery (42) and more than $80 \%$ of infants who develop neonatal herpes are born to women without any history of symptomatic herpes during pregnancy or at delivery $(40,43)$. While HSV-2 is implicated in the majority of neonatal herpes in the US, there is evidence that HSV-1 neonatal disease is more common in Canada $(44,45)$. It has been suggested that pregnant women be routinely screened for HSV antibodies because seronegative women could benefit from taking precautions to avoid the risk of primary infection during the third trimester $(46,47)$. However, at this time, this is not cost-effective, and because HSV TSS may not indicate anatomical location of infection, the interpretation of HSV-1 in asymptomatic women is problematic without also screening their partner (48). Regardless, the recognition and appropriate management of genital herpes in pregnancy is exceedingly important. Therefore, from a public health standpoint, it is prudent to consider targeted screening of asymptomatic pregnant women whose partners have a history of genital herpes. In this context, HSV TSS is useful in identifying pregnant women with either unrecognized HSV-2 genital infection or at risk of acquiring HSV-1 or HSV-2. For women who develop their first clinical episode of genital herpes during pregnancy, it is very important to document seroconversion and to make an appropriate recommendation for the mode of delivery. HSV TSS may also be considered for those who are contemplating pregnancy or considering a sexual partnership with an individual with a history of genital herpes. Such an approach may help reduce the risk of HSV acquisition and transmission by education and preventive counselling $(7,33)$.

The clinical suspicion of genital herpes should always be confirmed by laboratory testing because of the inherent inaccuracies of a clinical diagnosis and because determining the virus type will influence patient management and counselling. The challenge for the clinician is to determine when and how to test for genital herpes infection. In clinically recognized cases with lesions, the diagnosis can be made by HSV antigen detection by direct fluorescent antibody test or EIA, or by viral culture. However, the virus is only present for a short period, and particularly in recurrent infections, it is shed at lower concentrations (49). The ability to detect the virus is reduced if lesions are crusted and if recurrences occur infrequently. For such cases, both HSV antigen detection methods and culture have limited sensitivity $(12,13,17)$. While detection of the viral antigen or virus by these methods confirms the diagnosis, a negative result does not exclude it. In this context, the use of HSV PCR and TSS has been found to be of benefit in a number of clinical situations (16-18).

\section{NATs}

NATs are currently the most sensitive methods for the direct detection of HSV. A wide variety of NATs have been reported, and of these, the PCR-based assay has proven to be the best method in terms of sensitivity and specificity (50). In a recent comprehensive study (12), HSV viral culture was compared with PCR for over 36,000 genital specimens collected from patients with a variety of clinical histories and HSV infection status. Specimens were obtained from both males and females,
HIV-positive and HIV-negative, and in the presence and absence of lesions. The results confirmed that PCR is 4.1 times more sensitive than culture in detecting HSV infection, and the difference is particularly marked in specimens from women without lesions, with PCR being 10- to 14-fold more sensitive (12). To gain further insight, we carried out a review of 24 studies reported between 1991 and 2005 that compared the sensitivity of various types of NAT methods with culture. In most of these studies, the specimens were derived from patients with lesions suggestive of oral or genital HSV infection. Despite the wide range of collection and processing techniques and divergent characteristics of patients and specimens utilized in these studies, the review indicated that the overall sensitivity of culture relative to NAT methods was $69.9 \%$ (51). In particular, NATs can detect HSV with improved sensitivity in lesions that have progressed past the vesicular stage $(12,17,52)$. Along with a very high sensitivity, NAT methods also have specificity consistently close to $100 \%$ (53-56). In addition, NATs are much less affected by specimen storage beyond $48 \mathrm{~h}$ or by freezing, thawing, bacterial contamination and other factors that reduce virus viability $(57,58)$.

Virus isolation in cell culture remains the main diagnostic test for clinical laboratories worldwide including many, if not the majority of Canadian laboratories. Two reasons are often cited to support the continued use of culture, namely, low cost and well-established methodology. By contrast, PCR is more expensive and requires dedicated laboratory areas adapted to its use; there is a lack of a standardized method for the detection and typing of HSV nucleic acids. However, implementing NATs for genital herpes can be readily accomplished because many diagnostic laboratories are already set up for PCR assays. Additionally, PCR techniques have been used for many years for the diagnosis of HSV infections of the central nervous system (59-62). Real-time PCR methods are more appealing for routine diagnostic applications because they have better characteristics of reproducibility, standardization and faster turnaround time. Real-time PCR based on fluorescence resonance energy transfer technology can provide a type-specific diagnosis of HSV in $2 \mathrm{~h}$ to $3 \mathrm{~h}$ on the basis of the melting curve of the amplified products. These methods have been extensively validated in many studies (63-68) conducted in clinical settings, and have the potential for automation. The sensitivity of real-time PCR methods has been reported to be comparable with, or slightly lower than, some home brew methods $(63,69)$. Rare polymorphisms of both HSV-1 and HSV-2 DNA sequences may produce intermediate melting curves in some commercial real-time PCR kits $(65,70)$. Further interpretation of these indeterminate results is necessary to achieve $100 \%$ specificity in HSV typing (70). NAT methods based on TaqMan (Applied Biosystems, USA) technology (71) have also been developed and allow detection and typing of HSV-1 and HSV-2 with timeliness, sensitivity and specificity similar to tests performed using fluorescence resonance energy transfer technology $(69,72-75)$. The availability of these tests from commercial sources and their extensive validation allows for the application of this technology in routine clinical laboratory settings with consistency and greater diagnostic accuracy $(76,77)$.

\section{HSV TSS}

HSV TSS is a valuable second-line tool that assists in the diagnosis of individuals with genital herpes. While the use of HSV 


\begin{tabular}{|c|c|c|c|}
\hline Test & Population tested & $\begin{array}{c}\text { \% Sensitivity } \\
(95 \% \mathrm{Cl})\end{array}$ & $\begin{array}{c}\text { \% Specificity } \\
(95 \% \mathrm{Cl})\end{array}$ \\
\hline \multirow[t]{4}{*}{ HerpeSelect-1 } & Unselected & $83^{\dagger}$ & $90^{\dagger}$ \\
\hline & & $100^{\ddagger}$ & $98.3^{\ddagger}$ \\
\hline & STI clinic patients & $89 \S$ & $89 \S$ \\
\hline & Pregnant women & $96 \S$ & $95 \S$ \\
\hline \multirow[t]{5}{*}{ HerpeSelect-2 } & Unselected & $100^{\ddagger}$ & $95.7^{\ddagger}$ \\
\hline & & $98^{\dagger}$ & $96^{\dagger}$ \\
\hline & STI clinic patients & $97.7(86.5-99.9)^{\pi}$ & $94.5(83.9-98.6)^{\pi}$ \\
\hline & & $96 \S$ & $97 \S$ \\
\hline & Pregnant women & $100 \S$ & $96 \S$ \\
\hline
\end{tabular}

${ }^{*}$ Focus Technologies (USA). Data from references $+91, \ddagger 86, \$ 17$ and $\pi_{84}$. STI Sexually transmitted infection

TSS for routine screening is not recommended, its targeted use for specific diagnostic situations and in selected populations is of considerable benefit $(13,15,16,33)$. For example, HSV TSS is indicated when antigen detection, culture and NAT methods are not available or cannot confirm the clinical diagnosis, for risk stratification and management of HSV discordant couples and asymptomatic pregnant women whose partners have a history of genital herpes, for defining whether women who acquire primary herpes in pregnancy have seroconverted before labour and delivery, and determining the HSV serostatus of women contemplating pregnancy or considering a sexual partnership with those with genital herpes $(16,78,79)$. In addition, HSV TSS testing has a role in the management of HIVinfected patients $(16,33,37)$. Furthermore, the US Centers for Disease Control and Prevention (13) recommends that HSV TSS should be available in clinical settings that provide care for patients with sexually transmitted diseases or at risk for sexually transmitted diseases. Finally, the changing epidemiology of HSV-1 and HSV-2 has implications for serological testing (80).

There are many commercial serological tests for detection of HSV antibodies, not all of which can distinguish HSV-1 antibodies from HSV-2 antibodies (81). Because this may not be readily discernible from product labelling, it is important for diagnostic laboratories to be aware of tests that can accurately differentiate HSV-1 from HSV-2. Most Canadian laboratories that provide HSV serology appear to use commercial EIAs that do not distinguish between antibodies to HSV-2 from antibodies to HSV-1. It is also important to note that certain Health Canada approved commercial EIA kits that claim to differentiate between HSV-1 and HSV-2 antibodies are based on crude viral antigen mixture for HSV- 1 and HSV-2 and their use could result in spurious findings. For example, the Wampole (Wampole Laboratories, USA), Zeus (Zeus Scientific, USA) and Diamedix (Diamedix Corporation, USA) tests have shown a high level of cross-reactivity in the range of $47 \%$ to $82 \%$ with HSV-1 and HSV-2, along with an overall relatively low specificity compared with Western blot (81). The College of American Pathologists (USA) proficiency program has indicated that non-gG-based HSV EIAs yielded false-positive rates in the range of $14 \%$ to $88 \%$ for HSV-2 antibodies in sera that were positive for HSV-1 antibodies only (82).

Serological tests for the diagnosis of genital herpes must be type-specific and must be able to overcome the extensive serological cross-reactivity between HSV-1 and HSV-2. HSV TSS is challenging because the two viruses share greater than $70 \%$ identity at the level of their genome sequence. In fact, it has been observed that in individuals with previous exposure to HSV-1, a new infection with HSV-2 may result in a brisk and pronounced anamnestic HSV-1 antibody response as well as an HSV-2 antibody response (14). Of over 80 proteins encoded by their respective genomes, only gG, designated as gG-1 and gG-2 for HSV-1 and HSV-2, respectively, has proven to date to be clinically useful to differentiate antibody response between these viruses $(17,83)$. A number of HSV type-specific EIAs based on gG-1 and gG-2 are commercially available (15). Numerous reports $(14-16,18,79,81,84,85)$ have been published on gG-based TSS and their applications including evaluations of commercial test kits. HerpeSelect-1 and HerpeSelect-2 (Focus Technologies, USA) are gG-based type-specific tests for HSV-1 and HSV-2, respectively, and, on extensive evaluation, have been shown to have a high level of sensitivity and specificity in comparison with Western blot $(17,84,86,87)$ (Table 1$)$. Both serum and plasma are acceptable for testing (88). The time to detect seroconversion is variable, with the median time being approximately three weeks with the HerpeSelect-1 and HerpeSelect-2 tests versus four to 12 weeks with Western blot $(87,89)$. On the other hand, there is no evidence that immune response to HSV wanes over time or that seroreversion occurs, even with treatment, although transient false-negative results have been noticed with the HerpeSelect tests $(14,89)$. It is also worth noting that HIV status does not appear to affect the overall performance of this test (90). While HSV-2 TSS reactivity is considered synonymous with genital herpes, HSV-1 TSS is not specific to an anatomical location. Reactive HSV-1 serology may indicate either oral or genital herpes. More importantly, there is a high prevalence of HSV-1 in the general population, further limiting the interpretation of a positive result. For these reasons, some clinicians and laboratory professionals argue that HSV-1 serology is not clinically useful and, thus, should not be routinely offered. A counterargument is that a positive HSV-1 antibody test confirms immunity against HSV-1 and that a patient is no longer at risk for HSV-1 infection, but continues to be at risk for HSV-2 infection. In addition, a clinician can also use this information to review transmission risk from oral to genital sites, particularly in the current context in which HSV-1 genital herpes is surpassing HSV-2 in many regions across Canada (28, unpublished data).

As with any EIA test, equivocal results may be occasionally encountered with HSV TSS. In such instances, first, it is important to ensure all controls are working satisfactorily. On confirming this, the standard protocol should be to request a follow-up specimen. In circumstances where the patient is considered at risk, equivocal results could represent seroconversion phase. If repeat EIA results remain equivocal, HSV Western blot testing should be considered if deemed clinically necessary.

Western blot using whole infected cell lysate is a highly sensitive and specific diagnostic tool and provides accurate determination of type-specific antibody status (14). It has been available for a number of years, and, in particular, the University of Washington (USA) Western blot has undergone extensive validation and is considered to be the gold standard in the US (14). Despite the advantages, the 'classic' Western blot is not suitable for routine diagnostic applications because it is expensive, cumbersome and requires considerable technical expertise. In Canada, reference centres such as the National 
Microbiology Laboratory, Winnipeg, Manitoba, offer an in-house Western blot as a reference test.

Currently there are no tests available to distinguish longstanding HSV-2 infection from recently acquired HSV-2 once seroconversion occurs. HSV immunoglobulin M (IgM) antibodies appear initially with new infections and wane within two to three months, reappearing sporadically thereafter in conjunction with recurrences. Thus, in clinical practice, detection of IgM antibodies does not reliably signify recently acquired infection, and primary infection cannot be distinguished from a recurrent episode by IgM serology (14).

\section{RECOMMENDATIONS}

Because clinical diagnosis of genital herpes alone can be both insensitive and nonspecific, it should be confirmed by laboratory testing for the virus or by HSV TSS. This should be performed in conjunction with HSV education and counselling of infected persons and their sex partners. PCR, with its consistently and substantially higher rate of HSV detection, should be the test of choice for symptomatic cases. In certain diagnostic situations and selected populations, the targeted use of HSV TSS is recommended (Table 2). Based on published studies, HerpeSelect EIA is recommended as the test of choice for HSV TSS. However, the positive predictive value of HSV TSS will be lower in low prevalence populations and, hence, there is potential for false-positive findings. Therefore, HSV TSS is not recommended for routine screening, and when used, test results should be interpreted in the context of clinical presentation and patient history. There is evidence to support the use of HSV PCR and/or TSS for diagnostic and screening purposes in the following situations in the Canadian setting.

\section{Diagnosis of genital herpes}

The PCR assay is the test of choice for the diagnosis of genital herpes in symptomatic patients presenting with lesions. HSV-2 TSS testing is indicated for patients with a history of genital lesions in whom HSV could not be detected by antigen tests, culture or PCR. In addition, HSV-2 TSS testing is indicated for asymptomatic patients with a history suggestive of genital herpes. A negative HSV-2 TSS cannot rule out HSV-1, and where there is clinical suspicion, HSV-1 TSS may be warranted. TSS should be performed or repeated on specimens collected at least six weeks after exposure to ensure that the antibody response has occurred.

\section{High-risk populations for HIV}

HSV PCR or HSV-2 TSS may be offered, as appropriate, in clinical settings where patients are assessed for HIV. HSV-2 TSS is indicated for those diagnosed with HIV infection and such screening could provide the opportunity to improve health outcome and also serve as an adjunct to risk-reduction counselling. There is reported moderate evidence of efficacy or limited evidence with expert consensus supporting this recommendation (16).

\section{HSV discordant sexual partnership}

HSV TSS is indicated for evaluating asymptomatic partners of individuals diagnosed with genital herpes or having a history of genital herpes. In this setting, testing for both HSV-1 and HSV-2 may be necessary dependent on the partners' infection with HSV-1 or HSV-2. Support for this recommendation
TABLE 2

Herpes simplex virus (HSV) type-specific serology for genital herpes

HSV serology should be performed only with glycoprotein G-based tests. HSV type-specific serology is considered beneficial in selected populations who meet specific clinical criteria as outlined below

HSV-2 serology is indicated for diagnosing genital herpes in:

- Patients with recurrent or atypical genital lesions in whom a diagnosis

has not been confirmed by antigen detection, culture or PCR.

- Asymptomatic patients who have a history suggestive of genital herpes.

- Patients diagnosed with HIV infection.

HSV-2 serology, with HSV-1 serology as appropriate, is indicated for evaluating infection and or immune status in:

- Couples discordant for genital herpes.

- Women who develop their first clinical episode of genital herpes during pregnancy.

- Asymptomatic pregnant women whose partners have a history of genital herpes or HIV infection.

-Women contemplating pregnancy or considering sexual partnership with an individual with a history of genital herpes

Universal screening of pregnant women for HSV is not recommended.

The above testing should be offered in conjunction with education on HSV and preventive counselling. Although the tests are highly specific, there is potential for false-positive results. Results should be interpreted in the context of clinical presentation and patient history. PCR Polymerase chain reaction

comes from moderate evidence of efficacy or limited evidence with expert consensus (16).

At-risk pregnant women and women contemplating pregnancy or considering sexual partnership with those with genital herpes

HSV TSS is indicated for women who develop their first clinical episode of genital herpes during pregnancy to document seroconversion and immunity, and for those in their childbearing years with a history of suspicious lesions from which HSV could not be diagnosed by antigen detection, culture or PCR. HSV TSS is also indicated for asymptomatic pregnant women whose partners have genital herpes or HIV infection. Testing for both HSV-1 and HSV-2 may be necessary dependent on the partners' infection with HSV-1 or HSV-2. TSS for HSV-1 and HSV-2 may be used to identify HSV susceptibility in women who are contemplating pregnancy or considering entering into a sexual partnership with an individual with a history of genital herpes. These recommendations are supported by moderate evidence of efficacy or limited evidence with expert consensus (16). At this time, universal screening for HSV-1 or HSV-2 in pregnant women is not recommended, and this is supported by moderate evidence for lack of efficacy (16).

\section{CONCLUSIONS}

Optimal management of genital herpes and strategies to prevent its transmission include antiviral therapy to suppress viral shedding as well as education and counselling regarding the natural history of HSV, the risk of sexual and perinatal transmission, and preventive methods. This depends on accurate detection of infected persons. There is an unmet need for both PCR and gG-based HSV TSS for the diagnosis of genital herpes from the standpoints of patient care and management as well as public health in the Canadian setting, and these diagnostic services should be offered as appropriate and 
as recommended above based on current evidence. PCR and gG-based HSV TSS tests have a high level of sensitivity and specificity. However, these tests are not $100 \%$ specific and, therefore, there is potential for false-positive results. Falsepositive results have serious implications. Therefore, the characteristics of the test used and the population to be tested should be clearly understood and results should be interpreted in the context of clinical presentation and patient history.

DISCLAIMER: All authors have contributed equally in the preparation of the manuscript. The observations and recommendations made in the present paper are those of the authors and they do not represent the views of any professional organizations that the authors may be associated with.

ACKNOWLEDGEMENTS: The authors thank Dr Paul Van Caeseele (Cadham Provincial Laboratory, Winnipeg, Manitoba) for reviewing the manuscript and for his helpful criticisms, and Ms Debbie McGrath and Ms Elyse White (Public Heath Laboratory, St John's, Newfoundland and Labrador) for secretarial assistance. This work was supported by an unrestricted educational grant from GlaxoSmithKline Inc. Dr George Zahariadis receives research salary support from the Canadian Institute of Health Research and the Alberta Heritage Foundation for Medical Research. Presentations relating to this paper were made at the AMMI Canada-CACMID 2007 Annual Conference held in Halifax, Nova Scotia, from March 14 to 18, $2007(51,92,93)$.

\section{REFERENCES}

1. Corey L. The current trend in genital herpes: Progress in prevention. Sex Transm Dis 1994;21:S38-44.

2. Fleming DT, McQuillan GM, Johnson RE, et al. Herpes simplex virus type 2 in the United States, 1976 to 1994. N Engl J Med 1997;337:1105-11.

3. Brown ZA, Selke S, Zeh J, et al. The acquisition of herpes simplex virus during pregnancy. N Eng J Med 1997;337:509-15.

4. Freeman EE, Weiss HA, Glynn JR, Cross PL, Whitworth JA, Hayes RJ. Herpes simplex virus 2 infection increases HIV acquisition in men and women: Systematic review and metaanalysis of longitudinal studies. AIDS 2006;20:73-83.

5. Corey L, Wald A, Patel R, et al; Valacyclovir HSV Transmission Study Group. Once-daily valacyclovir to reduce the risk of transmission of genital herpes. N Eng J Med 2004;350:11-20.

6. Wald A, Langenberg AG, Link K, et al. Effect of condoms on reducing the transmission of herpes simplex virus type 2 from men to women. JAMA 2001;285:3100-6.

7. Wald A, Krantz E, Selke S, Lairson E, Morrow RA, Zeh J. Knowledge of partner's genital herpes protects against herpes simplex virus type 2 acquisition. J Infect Dis 2006;194:42-52.

8. Xu F, Sternberg MR, Kottiri BJ, et al. Trends in herpes simplex virus type 1 and type 2 seroprevalence in the United States. JAMA 2006;296:964-73.

9. Mertz GJ, Benedetti J, Ashley R, Selke SA, Corey L. Risk factors for the sexual transmission of genital herpes. Ann Intern Med 1992;116:197-202.

10. Hook EW, Leone P. Time to translate new knowledge into practice: A call for a national genital herpes control program. J Infect Dis 2006;194:6-7.

11. Ashley R, Cent A, Maggs V, Nahmias A, Corey L. Inability of enzyme immunoassays to discriminate between infections with herpes simplex virus types 1 and 2. Ann Intern Med 1991;115:520-6.

12. Wald A, Huang ML, Carrell D, Selke S, Corey L. Polymerase chain reaction for detection of herpes simplex virus (HSV) DNA on mucosal surfaces: Comparison with HSV isolation in cell culture. J Infect Dis 2003;188:1345-51.

13. Workowski KA, Berman SM; Centers for Disease Control and Prevention. Sexually transmitted diseases treatment guidelines, 2006. MMWR Recomm Rep 2006;55(RR-11):1-94.

14. Ashley RL. Sorting out the new HSV type specific antibody tests. Sex Transm Infect 2001;77:232-7.

15. Strick L, Wald A. Type-specific testing for herpes simplex virus. Expert Rev Mol Diagn 2004;4:443-53.
16. Guerry SL, Bauer HM, Klausner JD, et al. Recommendations for the selective use of herpes simplex virus type 2 serological tests. Clin Infect Dis 2005;40:38-45.

17. Wald A, Ashley-Morrow R. Serological testing for herpes simplex virus (HSV)-1 and HSV -2 infection. Clin Infect Dis 2002;35(Suppl 2):S173-82.

18. Ashley RL. Performance and use of HSV type-specific serology test kits. Herpes 2002;9:38-45.

19. Singh A, Preiksaitis J, Romanowski B. The laboratory diagnosis of herpes simplex virus infections. Can J Infect Dis Med Microbiol 2005;16:92-8.

20. Patrick DM, Dawar M, Cook DA, Krajden M, Ng HC, Rekart ML. Antenatal seroprevalence of herpes simplex virus type 2 (HSV-2) in Canadian women: HSV-2 prevalence increases throughout the reproductive years. Sex Transm Dis 2001;28:424-8.

21. Singh AE, Romanowski B, Wong T, et al. Herpes simplex virus seroprevalence and risk factors in 2 Canadian sexually transmitted disease clinics. Sex Transm Dis 2005;32:95-100.

22. Howard M. Sellors JW, Jang D, et al. Regional distribution of antibodies to herpes simplex virus type 1 (HSV-1) and HSV-2 in men and women in Ontario, Canada. J Clin Microbiol 2003;41:84-9.

23. Ratnam S, Head C, Chernesky M, et al. Herpes simplex seroprevalence in Newfoundland. Conjoint Meet CACMID, CHICA \& CIDS. Vancouver, November 4 to 8, 2001. (Abst)

24. Leone P, Fleming DT, Gilsenan AW, Li L, Justus S. Seroprevalence of herpes simplex virus-2 in suburban primary care offices in the United States. Sex Transm Dis 2004;31:311-6.

25. Janier M, Scieux C, Méouchi R, et al. Virological, serological and epidemiological study of 255 consecutive cases of genital herpes in a sexually transmitted disease clinic of Paris (France): A prospective study. Int J STD AIDS 2006;17:44-9.

26. Wald A, Zeh J, Selke S, Ashley RL, Corey L. Virologic characteristics of subclinical and symptomatic genital herpes infections. N Eng J Med 1995;333:770-5.

27. Sacks SL, Griffiths PD, Corey L, et al. HSV shedding. Antiviral Res 2004;63S1:S19-26.

28. Forward KR, Lee SH. Predominance of herpes simplex virus type 1 from patients with genital herpes in Nova Scotia. Can J Infect Dis 2003;14:94-6.

29. Ribes JA, Steele AD, Seabolt JP, Baker DJ. Six year study of the incidence of herpes in genital and nongenital cultures in a central Kentucky medical center patient population. J Clin Microbiol 2001;39:3321-25.

30. Löwhagen GB, Tunbäck P, Andersson K, Bergström T, Johannisson G. First episodes of genital herpes in a Swedish STD population: A study of epidemiology and transmission by the use of herpes simplex virus (HSV) typing and specific serology. Sex Transm Infect 2000;76:179-82.

31. Wald A, Zeh J, Selke S, et al. Reactivation of genital herpes simplex virus type 2 infection in asymptomatic seropositive persons N Engl J Med 2000;342:844-50.

32. Wald A, Corey L. Genital herpes. In: Holmes KK, Sparling PF, Mardh P, eds. Sexually Transmitted Diseases. New York: McGraw-Hill, 1999:285-312.

33. Guerry S, Allen B, Branagan B, et al. Guidelines for the use of herpes simplex virus (HSV) type 2 serologies: Recommendations from the California Sexually Transmitted Diseases (STD) Controllers Association and the California Department of Health Services (CA DHS). < http://www.stdhivtraining.net/pdf/ HSV guidelines.pdf> (Version current at July 10, 2007).

34. Wald A, Link K. Risk of human immunodeficiency virus infection in herpes simplex virus type-2 seropositive persons: A meta-analysis. J Infect Dis 2002;185:45-52.

35. Schacker T, Zeh J, Hu HL, Hill E, Corey L. Frequency of symptomatic and asymptomatic herpes simplex virus type 2 reactivations among human immunodeficiency virus-infected men. J Infect Dis 1998;178:1616-22.

36. McFarland W, Gwanzura L, Bassett MT, et al. Prevalence and incidence of herpes simplex virus type 2 infection among male Zimbabwean factory workers. J Infect Dis 1999;180:1459-65.

37. Strick LB, Wald A, Celum C. Management of herpes simplex virus type 2 infection in HIV type 1 -infected persons. Clin Infect Dis 2006;43:347-56.

38. Nagot N, Ouédraogo A, Foulongne V, et al; ANRS 1285 Study Group. Reduction of HIV-1 RNA levels with therapy to suppress herpes simplex virus. N Engl J Med 2007;356:790-9. 
39. Bryson Y, Dillon M, Bernstein DI, Radolf J, Zakowski P, Garratty E. Risk of acquisition of genital herpes simplex virus type 2 in sex partners of persons with genital herpes: A prospective couple study. J Infect Dis 1993;167:942-6.

40. Whitley RJ. Herpes simplex virus infections of women and their offspring: Implications for a developed society. Proc Natl Acad Sci USA 1994;91:2441-7.

41. Brown ZA, Wald A, Morrow RA, Selke S, Zeh J, Corey L. Effect of serologic status and cesarean delivery on transmission rates of herpes simplex virus from mother to infant. JAMA 2003;289:203-9.

42. Stone KM, Brooks CA, Guinan ME, Alexander ER. National surveillance for neonatal herpes simplex virus infections. Sex Transm Dis 1989;16:152-6.

43. Arvin AM, Hensleigh PA, Prober CG, et al. Failure of antepartum maternal cultures to predict the infant's risk of exposure to herpes simplex virus at delivery. N Eng J Med 1986;315:796-800.

44. Kimberlin DW, Lin CY, Jacobs RF, et al; National Institute of Allergy and Infectious Diseases Collaborative Antiviral Study Group. Natural history of neonatal herpes simplex virus infections in the acyclovir era. Pediatrics 2001;108:223-9.

45. Kropp RY, Wong T, Cormier L, et al. Neonatal herpes simplex virus infections in Canada: Results of a 3-year national prospective study. Pediatrics 2006;117:1955-62.

46. Brown ZA. HSV-2 specific serology should be offered routinely to antenatal patients. Rev Med Virol 2000;10:141-4.

47. Kinghorn GR. Debate: The argument for. Should all pregnant women be offered type-specific serological screening for HSV infection? Herpes 2002;9:46-7.

48. Arvin AM. Debate: The argument against. Should all pregnant women be offered type-specific serological screening for HSV infection? Herpes 2002;9:48-50

49. Reeves WC, Corey L, Adams HG, Vontver LA, Holmes KK. Risk of recurrence after first episodes of genital herpes. Relation to HSV type and antibody response. New Eng J Med 1981;305:315-9.

50. Scoular A. Using the evidence base on genital herpes: Optimising the use of diagnostic tests and information provision. Sex Transm Infect 2002;78:160-5.

51. Severini A, Romanowski B, Ratnam S, et al. Nucleic acid amplification tests and culture isolation for the detection of HSV in genital herpes. A literature review. Can J Infect Dis Med Microbiol 2007;18:87 (Abst).

52. Cone RW, Hobson AC, Palmer J, Remington M, Corey L. Extended duration of herpes simplex virus DNA in genital lesions detected by the polymerase chain reaction. J Infect Dis 1991;164:757-60.

53. Coyle PV, O'Neill HJ, McCaughey C, Wyatt DE, McBride MO. Clinical utility of a nested nucleic acid amplification format in comparison to viral culture for the diagnosis of mucosal herpes simplex infection in a genitourinary medicine setting. BMC Infect Dis 2001:1;11.

54. Coyle PV, Desai A, Wyatt D, McCaughey C, O’Neill HJ. A comparison of virus isolation, indirect immunofluorescence and nested multiplex polymerase chain reaction for the diagnosis of primary and recurrent herpes simplex type 1 and type 2 infections. J Virol Methods 1999;83:75-82.

55. Morse SA, Trees DL, Htun Y, et al. Comparison of clinical diagnosis and standard laboratory and molecular methods for the diagnosis of genital ulcer disease in Lesotho: Association with human immunodeficiency virus infection. J Infect Dis 1997;175:583-9.

56. Waldhuber MG, Denham I, Wadey C, Leong-Shaw W, Cross GF. Detection of herpes simplex virus in genital specimens by typespecific polymerase chain reaction. Int J STD AIDS 1999;10:89-92.

57. Wiedbrauk DL, Cunningham W. Stability of herpes simplex virus DNA in cerebrospinal fluid specimens. Diagn Mol Pathol 1996;5:249-52.

58. Jerome KR, Huang ML, Wald A, Selke S, Corey L. Quantitative stability of DNA after extended storage of clinical specimens as determined by real-time PCR. J Clin Microbiol 2002;40:2609-11.

59. Puchhammer-Stöckl E, Popow-Kraupp T, Heinz FX, Mandl CW, Kunz C. Establishment of PCR for the early diagnosis of herpes simplex encephalitis. J Med Virol 1990;32:77-82.

60. Rowley AH, Whitley RJ, Lakeman FD, Wolinsky SM. Rapid detection of herpes-simplex-virus DNA in cerebrospinal fluid of patients with herpes simplex encephalitis. Lancet 1990;335:440-1.
61. Aurelius E, Johansson B, Sköldenberg B, Staland A, Forsgren M. Rapid diagnosis of herpes simplex encephalitis by nested polymerase chain reaction assay of cerebrospinal fluid. Lancet 1991;337:189-92

62. Johnson G, Nelson S, Petric M, Tellier R. Comprehensive PCR-based assay for detection and species identification of human herpesviruses. J Clin Microbiol 2000;38:3274-9.

63. Kessler HH, Mühlbauer G, Rinner B, et al. Detection of herpes simplex virus DNA by real-time PCR. J Clin Microbiol 2000;38:2638-42

64. Koenig M, Reynolds KS, Aldous W, Hickman M. Comparison of Light-Cycler PCR, enzyme immunoassay, and tissue culture for detection of herpes simplex virus. Diagn Microbiol Infect Dis 2001;40:107-10.

65. Whiley DM, Mackay IM, Syrmis MW, Witt MJ, Sloots TP. Detection and differentiation of herpes simplex virus types 1 and 2 by a duplex LightCycler PCR that incorporates an internal control PCR reaction. J Clin Virol 2004;30:32-8.

66. Issa NC, Espy MJ, Uhl JR, et al. Comparison of specimen processing and nucleic acid extraction by the swab extraction tube system versus MagNA Pure LC system for laboratory diagnosis of herpes simplex virus infections by LightCycler PCR. J Clin Microbiol 2005;43:1059-63.

67. Whiley DM, Syrmis MW, Mackay IM, Sloots TP. Preliminary comparison of three LightCycler PCR assays for the detection of herpes simplex virus in swab specimens. Eur J Clin Microbiol Infect Dis 2003;22:764-7.

68. Legoff J, Bouhlal H, Grésenguet G, et al. Real-time PCR quantification of genital shedding of herpes simplex virus (HSV) and human immunodeficiency virus (HIV) in women coinfected with HSV and HIV. J Clin Microbiol 2006;44:423-32.

69. Ryncarz AJ, Goddard J, Wald A, Huang ML, Roizman B, Corey L. Development of a high-throughput quantitative assay for detecting herpes simplex virus DNA in clinical samples. J Clin Microbiol 1999;37:1941-7.

70. Issa NC, Espy MJ, Uhl JR, Smith TF. Sequencing and resolution of amplified herpes simplex virus DNA with intermediate melting curves as genotype 1 or 2 by LightCycler PCR assay. J Clin Microbiol 2005;43:1843-5.

71. Holland PM, Abramson RD, Watson R, Gelfand DH. Detection of specific polymerase chain reaction product by utilizing the $5^{\prime} \rightarrow 3^{\prime}$ exonuclease activity of Thermus aquaticus DNA polymerase. Proc Natl Acad Sci USA 1991;88:7276-80.

72. van Doornum GJ, Guldemeester J, Osterhaus AD, Niesters HG. Diagnosing herpesvirus infections by real-time amplification and rapid culture. J Clin Microbiol 2003;41:576-80.

73. Weidmann M, Meyer-König U, Hufert FT. Rapid detection of herpes simplex virus and varicella-zoster virus infections by real-time PCR. J Clin Microbiol 2003;41:1565-8.

74. Aryee EA, Bailey RL, Natividad-Sancho A, Kaye S, Holland MJ Detection, quantification and genotyping of herpes simplex virus in cervicovaginal secretions by real-time PCR: A cross sectional survey. Virol J 2005;2:61

75. Corey L, Huang ML, Selke S, Wald A. Differentiation of herpes simplex virus types 1 and 2 in clinical samples by a real-time taqman PCR assay. J Med Virol 2005;76:350-5.

76. Geretti AM, Brown DW. National survey of diagnostic services for genital herpes. Sex Transm Infect 2005;81:316-7.

77. Strick LB, Wald A. Diagnostics for herpes simplex virus: Is PCR the new gold standard? Mol Diagn Ther 2006;10:17-28.

78. Brown ZA, Benedetti J, Ashley R, et al. Neonatal herpes simplex virus infection in relation to asymptomatic maternal infection at the time of labor. N Engl J Med 1991;324:1247-52.

79. Song B, Dwyer DE, Mindel A. HSV type specific serology in sexual health clinics: Use, benefits, and who gets tested. Sex Transm Infect 2004;80:113-7.

80. Lafferty WE. The changing epidemiology of HSV-1 and HSV-2 and implications for serological testing. Herpes 2002;9:51-5.

81. Martins TB, Woolstenhulme RD, Jaskowski TD, Hill HR, Litwin CM. Comparison of four enzyme immunoassays with a western blot assay for the determination of type-specific antibodies to herpes simplex virus. Am J Clin Pathol $2001 ; 115: 272-7$

82. Morrow RA, Brown ZA. Common use of inaccurate antibody assays to identify infection status with herpes simplex virus type 2 . Am J Obstet Gynecol 2005;193:361-2. 
83. Tunbäck P, Liljeqvist JA, Löwhagen GB, Bergström T. Glyocoprotein $G$ of herpes simplex virus type 1: Identification of type-specific epitopes by human antibodies. J Gen Virol 2000;81:1033-40.

84. Turner KR, Wong EH, Kent CK, Klausner JD. Serologic herpes testing in the real world: Validation of new type-specific serologic herpes simplex virus tests in a public health laboratory. Sex Transm Dis 2002;29:422-5.

85. Cherpes TL, Ashley RL, Meyn LA, Hillier SL. Longitudinal reliability of focus glycoprotein G-based type-specific enzyme immunoassays for detection of herpes simplex virus types 1 and 2 in women. J Clin Microbiol 2003;41:671-4.

86. Prince HE, Ernst CE, Hogrefe WR. Evaluation of an enzyme immunoassay system for measuring herpes simplex virus (HSV) type 1-specific and HSV type-2 specific IgG antibodies. J Clin Lab Anal 2000;14:13-6.

87. Morrow RA, Friedrich D, Krantz E. Performance of the focus and Kalon enzyme-linked immunosorbent assays for antibodies to herpes simplex virus type 2 glycoprotein $G$ in culture-documented cases of genital herpes. J Clin Microbiol 2003;41:5212-4.

88. Cherpes TL, Meyn LA, Hillier SL. Plasma versus serum for detection of herpes simplex virus type 2 -specific immunoglobulin $G$ antibodies with a glycoprotein G2-based enzyme immunoassay. J Clin Microbiol 2003;41:2758-9.

89. Ashley-Morrow R, Krantz E, Wald A. Time course of seroconversion by HerpeSelect ELISA after acquisition of genital herpes simplex virus type 1 (HSV-1) or HSV-2. Sex Transm Dis 2003;30:310-4

90. Laeyendecker O, Henson C, Gray RH, et al. Performance of commercial, type-specific enzyme-linked immunosorbent assay for detection of herpes simplex virus type 2-specific antibodies in Ugandans. J Clin Microbiol 2004;42:1794-6.

91. Morrow RA, Friedrich D. Inaccuracy of certain commercial enzyme immunoassays in diagnosing genital infections with herpes simplex virus types 1 and 2. Am J Clin Pathol 2003;120:839-44

92. Romanowski B, Ratnam S, Severini A, et al. The diagnosis of genital herpes - beyond culture. Guidelines for the use of HSV type-specific serology and PCR. Can J Infect Dis Med Microbiol 2007;18:50. (Abst)

93. Zahariadis G, Severini A, Romanowski B, et al. Herpes simplex virus type-specific serology testing - it is long overdue. Can J Infect Dis Med Microbiol 2007;18:43. (Abst) 


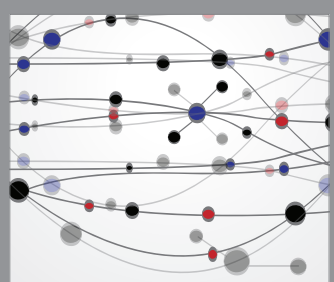

The Scientific World Journal
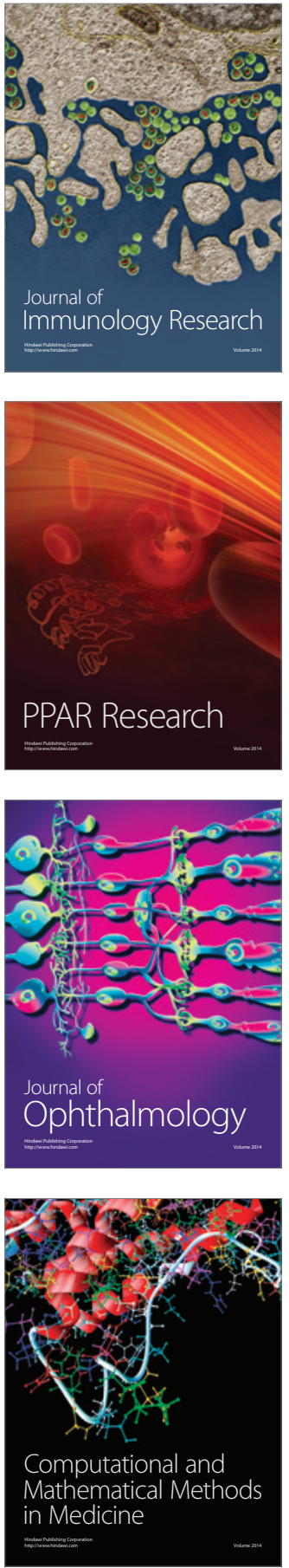

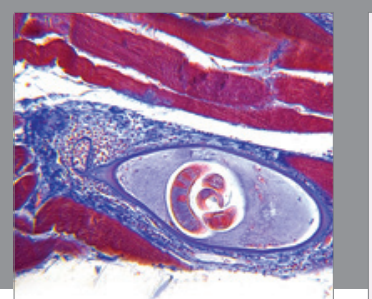

Gastroenterology Research and Practice

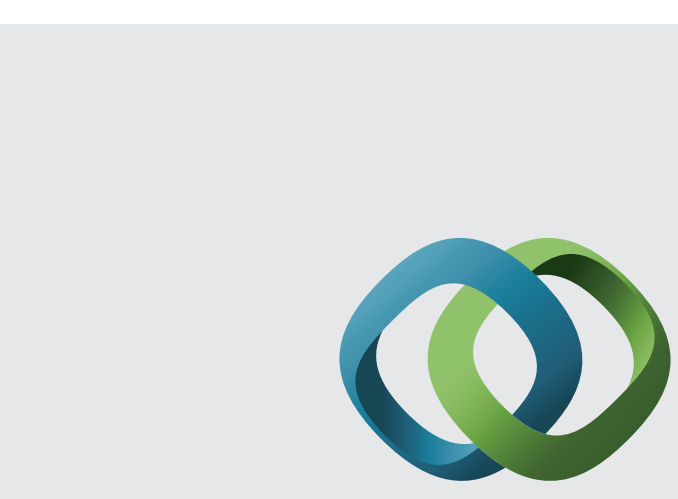

\section{Hindawi}

Submit your manuscripts at

http://www.hindawi.com
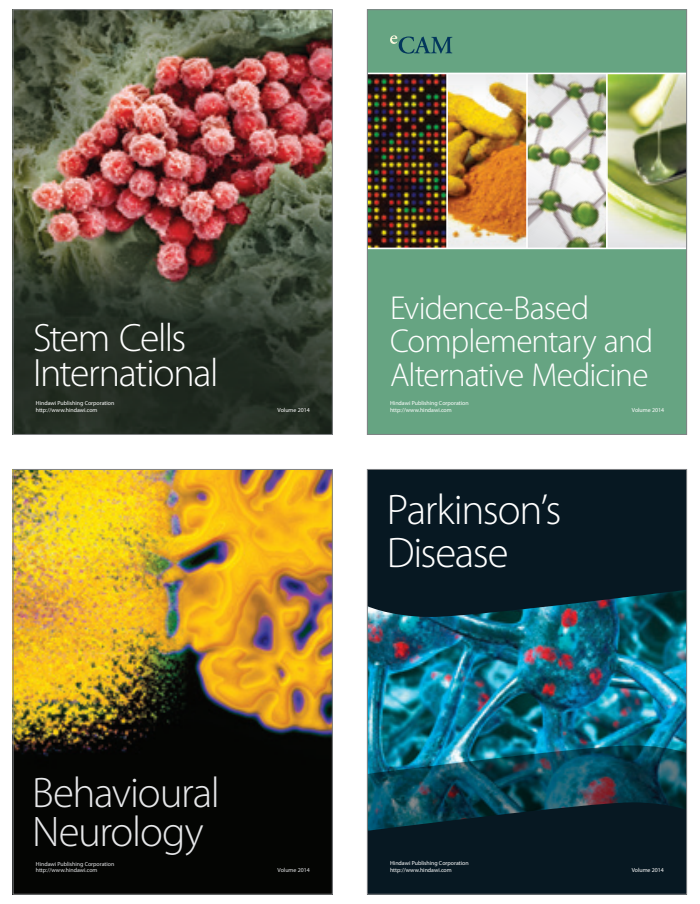
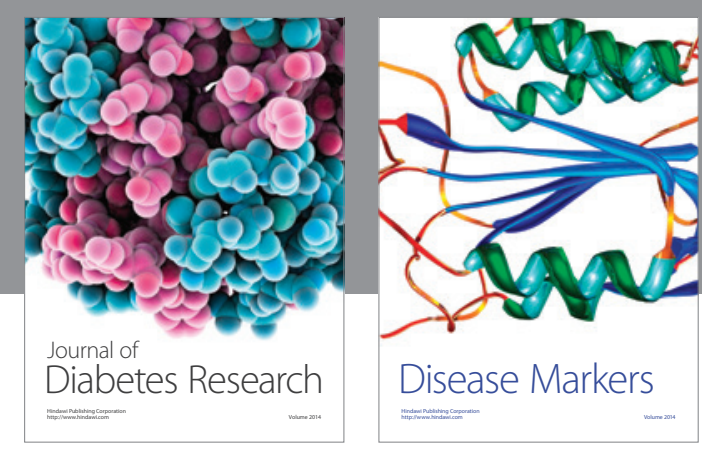

Disease Markers
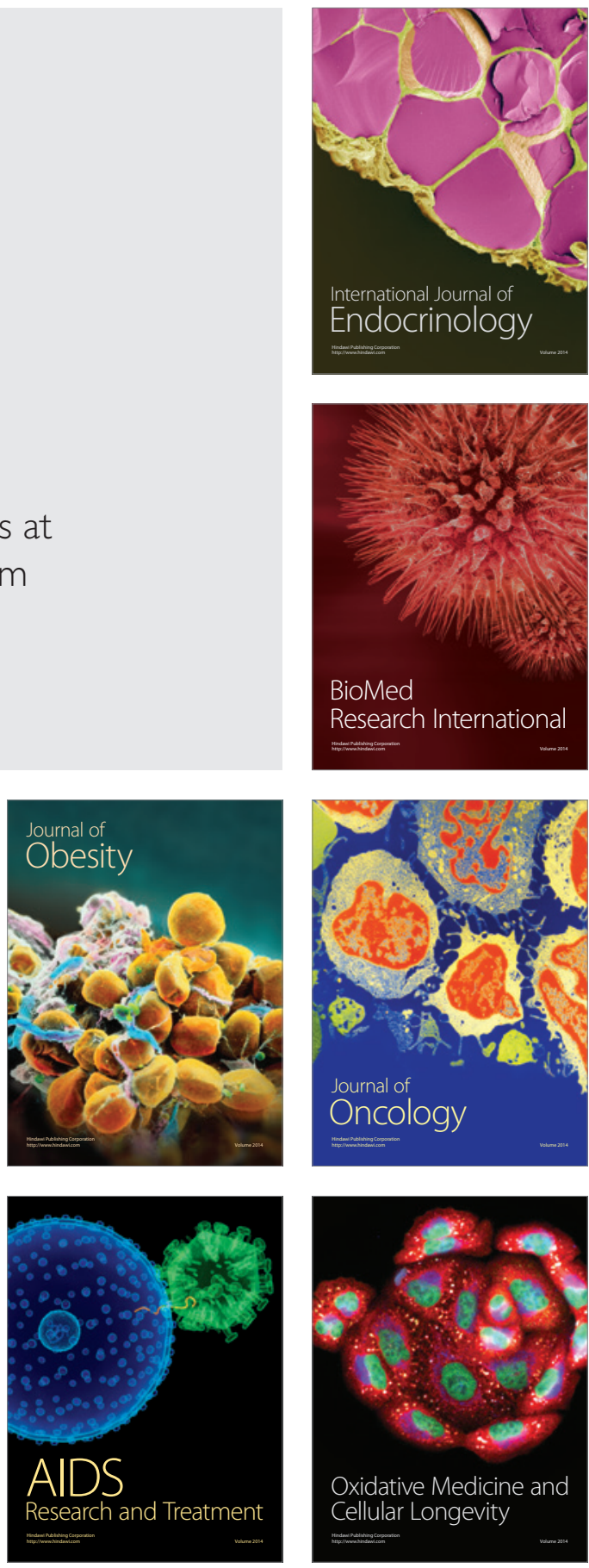